\title{
Against the factory school of modern times: the need of a paradigmatic rupture
}

DOI: $10.46932 / \mathrm{sfjdv2n2-194}$

Received in: March 1st, 2021

Accepted in: May 30th, 2021

\section{Jesus Maria Sousa}

Professor in Education at the University of Madeira, Portugal. She integrates the Advisory Board of the Portuguese Society of Educational Sciences (SPCE) and is co-chair of Red Iberoamericana de investigación sobre la calidad de la Educación Superior. She is also the Director of a $\mathrm{PhD}$ programme in Education, in Curriculum Studies and Pedagogical Innovation and has some experience in the evaluation of HEI in Europe.

E-mail: angi@staff.uma.pt

\begin{abstract}
Despite the accelerating change at all levels of life, demanding a plethora of new intelligent systems, formal education continues to resemble a box, created during Industrial Revolution and only modestly changed since. The technicist curriculum and the public school remain a modernist project, boxing in students and constraining their imaginations.

It is not worth investing in intelligent technologies if education is not taken into account, creating new flexibilities for people's behaviours and attitudes. A paradigm shift in the area of education and teacher education is a must.

The aim of this presentation is to share my concern about the inadequacy of the "black-and-white" mental organisation caused by the knowledge boundaries of various disciplines in hierarchical order, characteristic of the modernist curriculum implemented at schools, and the real need for a global and interdisciplinary methodological approach focused on the greatest problems of humanity.
\end{abstract}

Key-words: curriculum studies, paradigm shift, pedagogical innovation.

\section{INTRODUCTION}

First of all I would like to thank the Organising Committee for the invitation to be here. I guess you may be surprised to have someone related to the area of education to present a paper in this forum.

I want to stress the following idea:

In a new context of accelerating change at all levels of life, formal education insists being in the same box created at the times of Industrial Revolution and precautiously locked since then. Probably due to this resistance against change and innovation, education, as a scientific area, is not taken into account in the development of societies. Nowadays it is very difficult to find a research topic or priority related to education in the calls for big projects financed by public or private organisms.

And as an academic of the area of Curriculum Studies, this worries me a lot, because education has everything to do with knowledge and intelligence, with potentiality to create new flexibilities for 
people's behaviours and attitudes. But I also agree that a paradigmatic shift is necessary in the way that school works nowadays.

Still at the introductory level I should say that there is a direct relation between the school and the curriculum (meaning everything we learn at school, after all losses operated since it was idealized (ideological curriculum), written (formal or official curriculum), understood by the school (perceived curriculum), put into practice by the teachers (operational curriculum), and finally experienced by the students (experiential curriculum). As we see, the real curriculum covers a small part of the official curriculum. But on the other hand, being everything that is learned at school, it also covers a large part surreptitiously conveyed through attitudes, relations, organization and functioning of the school, such as social and sexual roles, that is, the hidden curriculum.

In any case, the core of the curriculum is knowledge, be it understood as content, subject-matter, attitudes, abilities, skills, competences. So why is there such inadequacy between school and the other systems?

\section{THE FACTORY SCHOOL OF MODERN TIMES}

The school we still have is a product of Modernity. And we all know that Modernity appears in a framework of rupture with the past, the Medieval Ages, having roots in the Renaissance, founded on the Protestant Reformation, assumed as a social project by the French Revolution, gaining more strength in the transition from the nineteenth to the twentieth century, supported by an absolute belief in science and technology as the only means to solving social or natural problems that plagued humanity. These were the four great pillars of Modernity: Renaissance, Reformation, French Revolution and Industrial Revolution, in a break with the medieval dogmatic and religious tradition, defending rational science, rationality with no metaphysics (WEBER, 1968).

According to Andy Hargreaves (1998), Modernity is a social condition that is guided and sustained by the Enlightenment beliefs in rational scientific progress, the triumph of technology over Nature and the ability to control and improve the human condition through the application of this source of knowledge and scientific and technological expertise to the field of social reforms.

In an attempt to better describe it, he relied on four levels of analysis: the economic, the political, the organizational, and the personal levels.

At the economic level, this author considers that Modernity marks the transition from the family's working place, where everything was done a little, to the factory, where specialization reaches its maximum, initiating the process of serial production, characteristic of capitalist monopoly or state socialism, as ways of increasing productivity and efficiency. The work processes become highly 
specialized, separating managers from workers, planning from execution, the work of thinking from the work of doing.

At the political level, he associates Modernity to the consolidation of the Nation-State as a military force, a welfare State which regulates the relationship between, on the one hand, education, health and social security and, on the other hand, the economy. It was supposed that the centralization of power, directly linked to decision-making, and the application of Keynesian economic policies, would make the State stronger and more interventionist, that is, a planned, paternalistic state that "protects and watches over the population in broader areas of regulation, control and intervention" (op cit .: 30).

At the organizational level, these principles are reflected in heavy bureaucratic processes, strongly and hierarchically segmented into divisions of technical competence.

Finally, at the personal level, he considers that the organization of this type of system, with this kind of order, if on the one hand could build some sense of identity and collective belonging, on the other, could also lead to alienation dictated by rational impersonality.

These principles were reflected in the Modernity school: for example, Learning stopped being a natural process within the family, to be developed in a specific place, the school, with specializing tasks and covering as many children and young people as possible, importing from the factory the idea of serial production.

Mass teaching could be, in the end, a very powerful means of domesticating minds, disciplining attitudes and habits (such as punctuality, for example, in a logic of division of time into equal parts, whether it was sunny or rainy, which was not so easy for those who were accustomed to working in the countryside, in a time regulated by the seasons). Those attitudes and habits were needed for greater productivity. As in the factories, it was important to achieve maximum efficiency, with a minimum of time and cost. The technical rationality that permeated the world of work, in a context of Industrial Revolution, thus accentuated the relation between means and ends.

In 1911, Frederick Taylor had developed for industry a theory of scientific management based on the so-called "job analysis", that is, a detailed analysis of gestures, sequences and times required for the execution of tasks. This reminds us Charlie Chaplin's "Modern Times".

The curriculum model proposed by Franklin Bobbitt was intended to transfer to the school this culture of scientific efficiency and effectiveness, inspired by the factories, since "education was a process of molding as much as the manufacture of steel rails." (1918: 259).

The logical ordering and control through elements such as the bell, the synchronization of tasks, the concentration of people in a closed building, the stratification by years and levels of education, the division of students by age, the assumption of two social classes (teachers, on the one side and students, 
on the other one), and, above all, the fragmentation of knowledge, putting aside emotions and affections, all this marked the factory school of modern times.

The "scientific management" of education required a precise design, aiming to achieve general and specific objectives, categorized into cognitive (Bloom et al., 1956), affective (KRATWOHL, 1972) and psychomotor (Harrow, 1972) objectives, and deployed into many behavioral and operational objectives (MAGER, 1976; 1977), without any kind of social, political or even epistemological questioning. The Rationale Tyler, as a linear and prescriptive theory of instruction, inaugurated the technicist curriculum, centered on "how to teach?" (about methods and techniques of teaching), rather than "what to teach?" or "what for?".

As Toffler says, the "general idea of gathering crowds of students (raw material) to be processed by teachers (workers) at a central school (factory) was a demonstration of industrial genius". (1970: 393).

Therefore, we can say that this school was in perfect harmony with the modern world that glorified the fragmentation of knowledge, objectivity, simplification, productivity and effectiveness under the command of teaching, instruction and didactics.

But are these the times we live?

\section{PARADIGMATIC RUPTURE}

The answer seems obvious. We all feel that we live a time of change, and change in meteoric acceleration. We feel this not only in the small things of everyday life, in our routines, social habits and behaviors, personal and family relationships, as well as in the organizational structures, new professions and scientific areas, missions and strategies of institutions, ideologies that animate social tensions, civilizational values and, above all, in the way of thinking. We live, as Sousa Santos (1988) says, a moment of transition of paradigms, not only societal as also epistemological paradigms.

And as an educational researcher, I am aware that in this new scenario of paradigmatic transition, there is no longer space for absolute certainty, nor for security and stability. On the contrary, it prevails the certainty of uncertainty, the systematic doubt, a growing awareness of discontinuity, rupture, and nonlinearity. For Edgar Morin (1990), we are facing a new order that also contemplates disorder; a new order that rejects the Manichean division arranged in reason and emotion; right and left; in man and woman; in black and white, when our times are times of interbreeding mestizaje.

Has it to do particularly with the social and human sciences? The answer is No. All science has been re-signified, with the participation of the "hard" sciences themselves. May be this revolution started from Edwin Hubble (1889-1953), when he succeeded in proving that the Milky Way was not the whole universe in 1929, but that the universe is constantly expanding: the conclusion was drawn from the finding 
of nebulae in other galaxies moving away from us at tremendous speeds. This discovery raised the question about the origin of the universe, giving bases to the Big Bang theory formulated by Georgy Gamow (1904-1968), a Russian-born American physicist.

Nevertheless it would be Albert Einstein (1879-1955), who initially resisted to the idea of a cosmic origin, to question Newton's independent concepts of space and time, presenting the idea of spacetime as one geometric entity, with his theory of relativity (special relativity in 1905 and general relativity, in 1915, this latter adding the effects of gravity to the former).

Gaston Bachelard (1993), when referring to the era of the new scientific spirit, as opposed to the pre-scientific and scientific phase, clearly states that it is this first date (1905) to mark the birth of the "new scientific spirit", opening the way to more audacious abstractions and reasoning. They are for instance the quantum mechanics of Max Planck (1858-1947) and the probabilistic theories, the wave mechanics of Louis de Broglie (1892-1987), the correspondence and complementarity theories of Niels Bohr (1885-1962) and the uncertainty principle of Werner Heisenberg (1901-1976) and many others who brought a new conception of physics which already contemplates the irregularities, disruptions and disintegrations, and acknowledges the inevitable interference of the subject in the observation, striking down the absolute vision of what is "reality."

Thus the concept of science gains a new meaning, in rupture with the prevailing paradigm, understanding it as "... what the members of a scientific community have in common", according to Kuhn (1983: 240). Thomas Samuel Kuhn (1922-1996) brought a new vision onto the development of science, by arguing that it does not evolve gradually and cumulatively, but through abrupt changes of paradigms.

This position makes us look at science differently and raise questions on scientific theories: Are they descriptions of the "reality"? Or are they just instruments that allow us to better understand the "reality" until other better explanations emerge? Popper's principle of falsifiability underlines the idea that a theory is scientific only if it can be refuted. "Je les conçois les théories scientifiques comme autant d'inventions humaines, comme des filets créés par nous et destinés à capturer le monde" (Popper, 1984: 36).

The philosophy of mathematics itself, from the incompleteness theorem (also called theorem of un-decidability) of Kurt Gödel (1906-1978), recognizes that the rigor of mathematical measurement, like any other form of rigor, rests on a criterion of selectivity. Someone has always to "subjectively" select the "objective" criterion, instrument, test, in detriment of another.

There arises a new relative and complex order, spreading from the physical and natural world (from the hard sciences) to the human and social world. 
In this context, the book by Jean-Francois Lyotard, "La condition postmoderne", was published in 1979. Understanding "scientific knowledge as a kind of discourse", Lyotard (1984) faces postmodernism as the end of meta-narratives, that is, the end of the great explanatory schemas of the world, whether they are totalitarian ideologies, or systems of knowledge, as it has been the case of science. The absolute truths and the idea of science as "the source of all truth" are now rejected.

But are we living a stage of rupture or of evolution of Modernity?

Anthony Giddens, for example, considers that "we have not advanced beyond modernity, but we are living precisely a phase of its radicalization" (Giddens 2000: 35). When Gilles Lipovetski (2004) prefers to use the term hypermodernity instead postmodernity, he wants to convey the idea that there was not a break with modernity yet, as the prefix "post" implies, but an accentuation of typical characteristics of modernity, such as the individualism, the consumerism, the hedonism, etc.

But either you call it post-modernity (Lyotard, 1984), or radicalized modernity or late modernity (Giddens, 2000), liquid modernity (Bauman, 2006) or hypermodernity (Lipovetsky, 2004), among other designations, what is true is that we are living in a time marked by dizzying acceleration of change at all levels under the umbrella of information technology and communication, which have brought a new meaning to globalization. We are witnessing the collapse of the components which shaped the thinking and institutions of Modernity, as is the case with the school. Stability, permanence, security and certainty are hardly words that fit into our everyday lexicon nowadays.

So what to do? Is it possible for the school to ignore all this epistemological uproar when it deals with knowledge? Can the curriculum continue to insist on fragmented knowledge? In a TED conference entitled How schools kill creativity, greatly disseminated through the internet, Ken Robinson, speaking about the hierarchy of the disciplines that compose the curriculum, stated that "Every education system on Earth has the same hierarchy of subjects: at the top are mathematics and languages, then the humanities, and the bottom are the arts". Why does this happen? Does Robinson's statement merely emphasize a kind of natural order of things?

And if we consider the relationship between language and thought, we would say that the postmodern mental organization is based on the so-called "absolute relativism", on the systematic doubt against "universalizing presumptions" (Lyotard, 1984), in a permanent questioning of the neutrality and the universality of the reason, because "the postmodern world is fast, compressed, complex and uncertain" (Hargreaves, 1998: 10). 


\section{THE CURRICULUM IN THE SCENARIO OF PARADIGMATIC RUPTURE}

To be consistent with this theoretical framework, there must be a disruptive change, which is not easy. Institutions are burdensome and averse to change.

The paradigm rupture we have just described makes us educators change the focus of the Curriculum we have been accustomed to throughout the last centuries of schooling. Therefore I propose the following:

1. A shift towards interdisciplinary school projects to solve real problems, which are currently occurring in the neighborhood, in the municipality, in the Country or in the world, instead of fragmentation into disciplinary subject-matters without personal meaning;

2. A shift towards the development of competences, through the mobilization of knowledge, attitudes and values, in an integrated way, instead of mere insistence on contents to be conveyed by the teacher and given back by the student;

3. A shift towards a transverse development of ecological awareness, for a life in harmony with the environment, rather than the alienation that allows the exploitation of natural resources, as if they were inexhaustible;

4. A shift towards socio-constructivist learning processes, centered on Mathetics, instead of Didactics concerned with instructional procedures of the so-called "good teaching practices";

5. A shift towards systemic, horizontal and group communication using native language, foreign languages and digital literacy, instead of linear, vertical and one-direction communication, controlled by the teacher;

6. A shift towards the development of healthy eating habits and effective physical training as fundamental aspects of curriculum, instead of long hours sitting quietly as listeners in the classroom;

7. A shift towards the internalization of the concept of human species (and our survival), as inhabitants of planet Earth, instead of promoting an accentuated historical nationalism;

8. A shift in the political and pedagogical sense of inclusion and equity, rather than the intolerance that seeks at all costs the standardization of the different "other", or his/her exclusion;

9. A shift towards cooperative and participatory work at various levels (students, teachers, school principals, families, community, researchers, and rulers) instead of the civic apathy and competitiveness fueled by fierce individualism;

10. Finally, the recognition of the need for time, long time, for the student's free initiative, whether to rest or to be genuinely with friends, talking, playing, or dating, without being organized by the school.

So, taking back my introductory words, Education has to keep pace with the new scenario we live, in order to be taken into account for the change of people's behaviours and attitudes, being focused on the 
greatest problems of the humanity and creative ways to solve them. Scholars as Edward de Bono, Joy Paul Guilford or Robert Sternberg have been alerting to the fact that schools do not train divergent or alternative thinking, but just to answer to the expected teachers' questions. And doing that, they won't trouble the teachers' certainties. Are we prepared to welcome trouble-makers in our classrooms? It is well known that society praises conformists, but honours trouble-makers who make the world step forward.

"This is not unlike the trauma that was caused in the sixteenth century by the discoveries of Copernicus and Galileo. Many astronomers were silenced, imprisoned, or excommunicated because their theories challenged the premodern worldview of the religious and political leaders of the European society" (Jencks, 1992, p. 10). 